\title{
Para além de Salvador e do Recôncavo baiano: o culto aos santos na América Portuguesa
}

Beyond Salvador and the Recôncavo baiano: cult to the saints in Portuguese America

Tânia Maria Pinto de SANTANA •

Resumo: Este texto pretende discutir alguns aspectos ligados à questão dos poucos avanços da catequese católica entre os negros, proposta pelo Clero na América - tomando como referência a cidade de Salvador e seu Recôncavo. Esses estariam ligados à sobrevivência de práticas pré-cristãs entre os africanos e seus descendentes. Marcados pela presença dos elementos cósmicos em suas concepções religiosas, esses priorizaram em suas crenças, a relação com os elementos da natureza, fazendo prevalecer uma experiência religiosa que colocava à margem conteúdos básicos transmitidos através da doutrina e dos ritos instituídos pela Igreja Católica.

Palavras-chave: Catequese; Devoção; Colônia; Negros.

Abstract: This text intends to discuss some aspects referent to the few advances of the Catholic catechism among the blacks, proposed by the Clergy in America - taking as reference the city of Salvador and its Recôncavo. These would be linked to the survival of pre-Christian practices among the Africans and their descendants. Marked by the presence of the cosmic elements in their religious concepts, these prioritized in their beliefs, the relation with the elements from the nature, prevailing a religious experience that laid aside basic contents transmitted through the doctrine and the rites established by the Catholic Church.

Keywords: Catechism; Devotion; Colony; The black People.

A catequese católica na América Portuguesa tinha como principal objetivo divulgar e expandir o conteúdo sacramental da religião cristã, onde residiam os fundamentos da sua prática. Um dos objetivos da Igreja era a "salvação da alma" dos seus fiéis e a participação nos sacramentos era elemento fundamental para garantir o perdão das culpas causadas pelos pecados e a morada no paraíso celestial após a morte. Na doutrina católica eles recebiam atenção especial. A sua administração era considerada elemento fundamental da doutrina da justificação dos pecados humanos (DENZIGER, 1955, p.227-263).

As justificativas expostas acima estavam entre as que inspiraram a construção do culto aos santos negros, quer sejam os "santos nobres" como Sta. Ifigênia e Sto. Elesbão, através do qual se pretendia revelar a universalidade da Igreja cristã e incluir os negros entre o número dos sujeitos dessa mensagem de salvação, como também por meio do culto aos "santos escravos", S. Benedito e Sto. Antônio de Categeró, quando se colocava a escravidão como elemento fundamental no processo de salvação, como instrumento eficiente para expurgar os pecados transmitidos pelo paganismo. Entretanto, o que observamos na prática religiosa popular da sociedade colonial é uma ênfase em elementos considerados secundários pela teologia cristã para a salvação da alma, como

\footnotetext{
- Mestre em História - Professora do Centro de Humanidades e Letras - UFRB - Universidade Federal do Recôncavo da Bahia - CEP. 44380-000, Cachoeira, Bahia, Brasil. E-mail: tmpsantana@ig.com.br
} 
foi o culto aos santos taumaturgos, cujo sucesso deveu-se principalmente as suas intervenções miraculosas, capazes de trazer respostas eficazes para os problemas cotidianos.

Enquanto as missas, em 1712, nas igrejas matrizes e suas filiais eram assistidas regularmente por apenas $10 \%$ da população da Bahia, procissões, ladainhas, novenas e trezenas dedicadas aos santos proliferavam na capitania. O século XVIII caracterizou-se pelo crescimento do número de irmandades responsáveis por essas devoções. A prática sacramental perdia terreno num território cada vez mais dominado pelo culto aos santos, numa transposição para a colônia de uma realidade já observada desde a Idade Média nas sociedades européias (VAUCHEZ, 1995). Aqui, tais práticas atingiam todos os grupos sociais. Em 1756, Salvador, negro mina, morador em Caité Mirim, em Santa Rita, Bahia "dizia que não era preciso se confessar para a salvação" não dispensando, porém, a reza cotidiana da oração dos pastores e da ladainha de Nossa Senhora, que eram feitas de "joelhos com uma conta e um cilício na mão"1. O sacramento não era necessário, mas a oração aos santos sim. Não que os sacramentos tenham perdido a sua importância no cotidiano religioso popular. O batismo, por exemplo, era compreendido como uma forma de esconjuro do mal e os não batizados eram vistos como expostos a todo tipo de maldição. Mas a prática dos sacramentos reiterativos - a confissão e a comunhão -, ocorria com muita dificuldade.

Entre pretos e brancos proliferava-se na colônia o uso de objetos e orações ligados aos santos, que incluía rosários, bentinhos, escapulários e outros. Os próprios objetos ligados ao culto do Santíssimo Sacramento, a eucaristia, haviam sido convertidos em elementos capazes de trazer a cura e a proteção para o corpo de quem os trouxesse junto a si. Pedras d'aras, sanguinhos e pedaços do pão eucarístico (hóstia) eram constantemente furtados com esse fim. Esses costumes já eram antigos entre os ibéricos. Segundo Oliveira Marques, no século XV, as Constituições do Arcebispado de Lisboa protestavam contra o uso da hóstia consagrada e dos santos óleos do crisma para preparação de feitiços (OLIVEIRA MARQUES, 1974, p.171). Na Bahia, encontramos diferentes episódios protagonizados tanto por negros como pelos seus senhores, sendo um dos mais famosos, o de quatro negros, moradores em Jacobina, denunciados ao Tribunal da Inquisição em 1745 (MOTT, 1997; KARASCH, 1987; REIS, 1991)².

Ex-votos, relatos de milagres registrados por membros do clero, uso de relíquias, proliferação de oratórios públicos e particulares são evidências do crescimento desses cultos. Em muitos inventários de negros libertos, em Salvador, encontramos oratórios de santos listados entre os seus bens e em seus testamentos eles fazem referência ao papel protetor de muitos deles. Neste contexto marcado pelo apelo aos intermediários divinos, diretamente ligados aos aspectos mais terrenos da vida humana, a prática sacramental não conseguia impor-se entre os negros. Por outro lado, a prática de suas religiões ancestrais também permanecia. Em 1738, Frei Calixto de São Caetano, prior do Convento de São Bento, relata que os negros "não obstante serem logo catequizados, 
reduzidos a fé e batismo [...] não deixam contudo as superstições com que foram criados nas suas terras, juntando-se em congressos (se bem que ocultamente) para fazerem os seus calundus, danças profanas e outras funções" (Apud VIANA FILHO, 1946, p.108).

Aqui discutiremos sobre a sobrevivência das heranças religiosas ancestrais entre os africanos e seus descendentes e sobre o culto aos santos católicos taumaturgos vivenciados por estes na América Portuguesa. Nesse culto é possível perceber a predominância dos elementos cósmicos sobre o principal conteúdo da fé católica: o sacrifício do Cristo e o seu significado para a redenção dos homens e de suas culpas. Em posição secundária, era colocado o Deus transcendente, razão de todo o culto cristão, mas distante demais da vivência religiosa popular, que priorizou a relação com os elementos da natureza. Inúmeros relatos de cronistas, missionários e viajantes, além dos documentos de irmandades religiosas, quer escritos, quer iconográficos, atestam a experiência cristã vivida por um grande número de negros na colônia. Nossa pergunta é: como o negro tornou-se cristão e que tipo de cristianismo experimentou?

Os choques entre o cristianismo institucional e as diferentes tradições religiosas africanas ocorrem não apenas devido às razões apresentadas por D. Sebastião Monteiro da Vide, em carta enviada ao rei de Portugal durante o período em que foi arcebispo na Bahia (1702-1722). O arcebispo escreve, em 1712, sobre falta de recursos humanos e financeiros, impedindo um acompanhamento permanente da prática católica ${ }^{3}$. Acreditamos que tenha ocorrido principalmente devido a uma irreconciliável divergência entre essas tradições religiosas: a judaico-cristã, do Clero Católico, baseada no controle do universo por um Deus transcendente e acima da realidade histórica, ao qual todos os seres estão submetidos, e à cósmica, do mundo africano, baseada na concepção de que é possível aos homens estabelecer comunicação direta com as diferentes forças que controlam o mundo natural, tanto em vida quanto após a morte, cabendo a ele buscar os meios para estabelecê-la.

Neste estudo, partimos de um princípio que aplica o conceito de religião cósmica para as diferentes tradições religiosas africanas que foram trazidas para o Brasil, durante o tráfico de escravos. Ao fazermos isto, fomos levados muitas vezes a ponderar os riscos que envolviam tal leitura aparentemente "homogênea" do contexto religioso africano. A África é um continente que abriga grandes blocos culturais e religiosos. Aqui, nosso olhar recai sobre as religiões nativas africanas - elas mesmas frutos de contatos e assimilações -, trazidas para o Brasil por representantes de diferentes grupos étnicos, através do tráfico de escravos. Dos grupos trazidos para o Brasil, para a Bahia em especial, podemos destacar que foram provenientes do Oeste e da África Central ${ }^{4}$. Estas tradições religiosas apresentam importantes diferenças em seus conteúdos e rituais litúrgicos, demonstradas por estudiosos das culturas africanas. Por outro lado, todas apresentam um princípio que prioriza a relação com o cosmos e integra os diferentes elementos da natureza em seu culto 
(ELBEN, 1986. ELIADE; CLOULIANO, 1999. THOURTON, 1992. VERGER, 1999). Seus cultos seguem um modelo cósmico de visão do mundo. Ao afirmar isto não estamos insistindo numa pretensa "homogeneidade" religiosa entre esses grupos, indica apenas que pretendemos trabalhar com as zonas de convergências existentes entre suas crenças e valores. Assim, construiremos nosso texto, tomando como referencial não as especificidades desses cultos religiosos ancestrais, mas os seus elementos convergentes.

Longe de desconhecermos as complexidades que envolvem a dinâmica religiosa dos grupos africanos transportados para o Brasil, que inclui mudanças produzidas em seus conteúdos cultuais ao longo de vários séculos na África, produzidas por migrações, contatos inter-étnicos, imposição de tradições e deuses resultadas de guerras e conflitos entre linhagens, enfatizamos, porém, a existência de grupos de valores e crenças comuns que orientam a construção dos seus sistemas religiosos. O conhecimento sobre os sistemas religiosos africanos no período moderno tomou como referência não apenas a tradição oral, mas também relatos de missionários, viajantes e cientistas que estiveram no continente africano no período colonial. A despeito do caráter negativo dessas narrativas, que ora demonizam e ora barbarizam essas tradições culturais, elas são fontes que confirmam a antiguidade dessas crenças ancestrais e da sua transposição para a colônia.

Alguns autores têm reafirmado a necessidade de construir novos modelos para o estudo da realidade africana e da sua herança cultural na América. Na obra Na Senzala uma Flor, Robert Slenes remete a novas diretrizes que orientam os estudos sobre religião e família na África Central. Segundo ele, tais estudos refletem uma nova concepção de cultura que:

ao invés de agrupar os povos da África Central, como antes, em várias 'áreas culturais', definidas principalmente a partir de considerações sobre a vida material e intricados sistemas de parentesco, estes novos estudos identificam 'paradigmas', ou pressupostos básicos, que subjazem à idéias e práticas nas esferas da religião e da família (SLENES, 1999, p.143).

Slenes também cita Willy de Craemer, Jan Vansina e Renée C. Fox que argumentavam, em 1976, que “embora as diferenças entre as religiões da África Central sejam marcantes, certas constelações [ou conjunto de valores] são comuns a todas elas" (SLENES, 1999, p.148).

Para Sidney Mintz e Richard Price, o estudo da herança cultural africana no Novo Mundo deve tomar como referência os elementos comuns entre os vários sistemas culturais do Oeste e da África Central. Tais elementos devem ser buscados não em suas estruturas materiais, mas nos princípios de sabedoria e atitudes psicológicas que orientavam a vida em sociedade. Afinal, ao ser transportado para o Novo Mundo, o escravo vem desassociado de seu grupo étnico e deixa para trás instituições sociais, que não poderão ser reconstituídas de modo intacto no ambiente escravista. Assim, crenças e valores serão elementos fundamentais para a reorganização cultural dos africanos 
na América. Na Bahia, entretanto, a concentração de africanos provenientes da região yorubá permitiu uma reconstituição muito próxima do seu modelo institucional religioso, que resultou nos candomblés de tradição nagô. Por outro lado, a assimilação de outros grupos étnicos nesta prática religiosa, somente foi possível pelas convergências entre seus princípios, crenças e valores. Segundo Sidney Mintz e Richard Price, as religiões do Oeste e da África Central parecem ter compartilhado a crença: de que todos os fenômenos têm uma causa específica; também na habilidade para adivinhar e revelar tais causas; no papel ativo dos mortos na vida dos vivos; na responsabilidade das entidades divinizadas sobre as ações humanas; na relação entre enfermidades, conflitos ou infortúnios sociais (MINTZ; PRICE, s/d, p. 45).

Pierre Verger nos fornece um elemento de convergência que será muito importante em nosso estudo. Segundo ele, nas religiões da Nigéria (região yorubá) e do Daomé (grupo djèdjè) existe o conceito de que "as forças da natureza podem ser apaziguadas, recorrendo a associações, correspondências, afinidades e ligações entre certos elementos". Estes cultos "dirigem-se em princípio, às forças da natureza, através dos ancestrais divinizados, e constituem um vasto sistema que une os mortos e os vivos em um todo familiar, contínuo e solidário" (VERGER, 1999, p.16). Esta relação com o sagrado parte de um princípio de totalidade que integra não apenas a comunidade humana, mas a flora, a fauna, e o além, e em torno dela se constrói ainda hoje o culto promovido por diferentes grupos étnicos habitantes da África e por seus descendentes no Brasil.

\section{O Universo Religioso Católico: Tradição Judaico-Cristã versus Visão Cósmica}

As características convergentes nos diferentes sistemas religiosos africanos listadas acima remetem a uma visão cósmica da realidade humana. Segundo Eliade, a origem desta divinização do cosmos está nos tempos arcaicos, quando o homem já divinizava as regiões celestes devido a sua transcendência, e todos os elementos a ela relacionados - os astros, o trovão, o vento, dentre outros. A natureza era também divinizada na medida em que ela própria constituía-se em instrumento de manifestação deste sagrado (ELIADE, 1998). Já no mundo Antigo, as religiões remetiam a existência de dois mundos: um sensível aos sentidos humanos, habitado pelos elementos do mundo material; e um invisível, habitado por deuses, espíritos e pelos mortos. Os seres do mundo invisível se manifestam no visível por meio de revelações, com o objetivo de intervir no destino dos homens (sonhos, adivinhações, milagres, augúrios, etc). Os seres do mundo invisível podem se comunicar tanto através de uma possessão (num animal ou ser humano) ou pela manipulação de um sacerdote que conhece seus poderes (ervas curativas, rituais diversos, patuás, orações). Os elementos do cosmos eram divinizados na medida em que constituíam-se instrumentos de manifestação do sagrado, que lhes conferia uma personalidade própria, pois suas ações resultavam dos desejos dos 
deuses ou seres que os habitavam definitiva ou momentaneamente. Assim temos árvores, fontes, rios, pedras sagradas. O homem, nas diferentes tradições religiosas, buscava o conhecimento que lhe permitisse manter sob o seu controle a ação dessas forças, daí a necessidade constante de diferentes rituais, oferendas e sacrifícios. Na concepção yorubá, por exemplo, há uma troca permanente de energia vital entre os homens e as divindades, e os rituais são os mecanismos através dos quais elas se processam (ELBEN, 1986, p.39-52). Assim, como diz Eliade, "el mundo, la vida, la materia vivente adquiren dimensiones religiosas" (Apud MALDONADO, 1975, p.92).

O Cristianismo, porém, apoiou-se de modo fundamental, na concepção de mundo judaica. Os judeus, ao contrário dos outros povos da Antiguidade não aceitavam a divinização dos elementos da natureza, insistiam, ao contrário, na existência de um Deus transcendente. Um Deus que não habitava o universo cósmico, que o transcendia, era o Outro. Criador do mundo sensível, ou natural, mantinha-o submetido à sua vontade. Habitava o mundo invisível, transcendente, do qual o homem tinha conhecimento por meio da palavra revelada - a Torá, que transmitia a história desta interferência divina no cotidiano do povo judeu. A Igreja cristã apoiou-se dogmaticamente nessa fé revelada historicamente, centrando-a na figura de Cristo, encarnação de Deus, e de sua própria história. Dentro dessa compreensão do sagrado não era possível uma divinização dos elementos cósmicos, tudo ocorrendo por intervenção de Deus ou do diabo - ser que habitava o mundo espiritual e agia em oposição a vontade de Deus. Os sermões de S. Agostinho são exemplos dessa teologia. Num Sermão da Epifania, tratando sobre a estrela que teria guiado os magos do Oriente até o Messias cristão, S. Agostinho enfatiza a condição de Cristo como "Senhor desta estrela, não a elas sujeito" (AGOSTINHO, Bispo de Hipona, 1959, p.85). Mas, se insistisse nessa teologia apenas, marcada por uma dessacralização ou desencantamento da natureza, o cristianismo dificilmente teria tornado-se religião hegemônica no Ocidente. A dinâmica que orientou o seu crescimento foi uma "permissividade" em relação às reinterpretações do seu conteúdo teológico, processada pelas sociedades pagãs cristianizadas, em especial no que diz respeito à construção da liturgia cristã. A tensão entre essas duas formas de compreensão do sagrado tem sido uma constante na história do cristianismo. Uma foi adotada oficialmente, a outra foi constantemente alimentada pela tradição popular, onde reside o substrato das religiões pré-cristãs, e essas construções foram absorvidas tanto pela hagiografia quanto pela liturgia católica, expressando cada vez mais um caráter cósmico.

Esse intercâmbio entre o cristianismo e os elementos religiosos presentes em outras culturas com as quais ele interagiu permaneceu ocorrendo, dando origem a experiências cristãs que foram denominadas de diferentes formas por historiadores da cultura ou da religião. Segundo Vauchez o cristianismo popular dos séculos XII e XIV consistia "num conjunto de práticas comuns a muitas outras religiões e que se encontram em todas as civilizações tradicionais" (VAUCHEZ, 1995). A 
respeito dessas práticas, Jean Delumeau diz que eram resultados de estruturas mentais pré-coloniais, ou pré-industriais (DELUMEAU, 1986); Eliade o chamou de cristianismo cósmico (ELIADE; CLOULIANO, 1999); Luis Maldonado de cristianismo mágico (MALDONADO, 1975). Na África, John Thornton o denominou de cristianismo africano (THOURTON, 1992). Os historiadores brasileiros o chamam de cristianismo popular ou "sincrético". Tais experiências cristãs, com especificidades determinadas pelas culturas e períodos em que foram vividas, tiveram em comum a concepção cósmica da realidade.

Dentro de uma concepção de harmonia cósmica encontra-se, por exemplo, a crença na influência dos ritmos astrais sobre o destino dos homens e dos outros elementos do cosmos. Daí a necessidade de conjugar não apenas as celebrações humanas aos ritmos astrais, como de utilizar-se da influência do sol, lua e estrelas nas práticas curativas, divinatórias, amatórias e outras. As principais festas religiosas sempre estão definidas, quer no calendário cristão quer no das religiões ditas pagãs, dentro do tempo dos quatro momentos cardinais da rotação da terra ao redor do sol: os solstícios de verão (finais de junho) e de inverno (finais de dezembro) e os equinócios de primavera (finais de março) e de outono (finais de setembro), quando dia e noite têm uma duração equivalente (MALDONADO, 1975, p.136). Até o Concílio de Trento essas práticas foram assimiladas ao cristianismo, embora elas já fossem condenadas pelos primeiros doutores da Igreja. No sermão da Epifania citado acima, S. Agostinho condena veementemente a crença na influência dos astros sobre o destino humano. Sobre as práticas ditas pagãs ligadas a tal crença, ele diz que "os costumes depravados que os tornam detestáveis aos homens na terra, eles ousam atribuí-los ao céu e inventar que provêm da influência dos astros" (AGOSTINHO, Bispo de Hipona, 1959, p.85). Os homens precisavam deixar de crer que seus rituais poderiam influenciar o movimento dos astros, pois isto somente o Deus cristão poderia fazer. Os ataques sistemáticos ao longo da história do cristianismo não impediram, porém, a sobrevivência de tais crenças em grande parte das sociedades cristãs. Redigido no século XIV, em Portugal, o Penitencial de Martim Pérez condenava a crença em estrelas e signos. Em 1707, as Constituições do Arcebispado da Bahia condenava os que:

advinharem cousas secretas, e casos futuros, ainda que se faça juizo, e levantem figuras pelos movimentos do Sol, da Lua, Estrellas, e quaesquer outras cousas, salvo se forem aquellas, que pendem do movimento dos Ceos, e suas influências, força dos elementos, e efficacia das cousas naturaes, como são bom, ou mao tempo para as sementeiras, fructos, navegações, saude, doenças, e outros effeitos semelhantes, sem que se intromettão nos sucessos que dependem do livre alvedrio, e consequencias delles ${ }^{5}$.

Invocações ou cultos ao sol, à lua, às pedras e à água, à terra e a outros elementos da natureza eram interpretadas pela Igreja como superstições e supunham “[...] comércio, familiaridade e pacto 
com o demônio"6. A preocupação do clero colonial crescia na medida em que novos povos gentios eram introduzidos na capitania, podendo aumentar ainda mais a recorrência a tais práticas.

Segundo Oliveira Marques, a religião desempenhava destacado papel na sociedade ibérica. Pois "toda a vida quotidiana, do nascimento ao túmulo, se desenrolava sob o seu signo" (OLIVEIRA MARQUES, 1974, p.151). Os sacramentos eram os principais ritos da vida social portuguesa, mas eles não se descuidavam da doutrinação cristã. Entretanto, essa doutrinação consistia muito mais numa fixação das orações e de algumas doutrinas básicas da Igreja, como os 10 Mandamentos, do que de um aprendizado e compreensão da teologia cristã. Assimilado dentro de um contexto religioso que priorizava as relações com o cosmos, tal saber foi utilizado como mais um elemento de manipulação dessa realidade. Não é de admirar que raros foram os denunciados à Inquisição Portuguesa que, entre os séculos XVI e XVIII, não sabiam recitar tais orações junto ao Santo Ofício (MOTT, 1997, p.164-165). Oliveira Marques informa que desde a Idade Média "o Padre Nosso, o Credo, os Salmos, os próprios Evangelhos serviam para interpretações cabalísticas" (OLIVEIRA MARQUES, 1974, p.171). As orações - dos mais diferentes tipos - revestidas de caráter sagrado eram vistas como muito úteis no estabelecimento do contato com o mundo espiritual e com as forças do mundo natural. A despeito das tentativas do Clero de "purificar" a prática da religião cristã na sociedade ibérica, pouco mudou na vivência dessa religião.

$\mathrm{Na}$ Bahia colonial as orações foram utilizadas inúmeras vezes em rituais de cura e adivinhação. Consta na biografia de Soror Maria Victória da Encarnação, Madre do Convento de Santa Clara do Desterro, que ali viveu entre 1686 e 1715, que esta curava os enfermos "mais com orações do que com outros remédios" (JABOATÃO, 1859, p 729). Entre os denunciados à Inquisição estava Inácio Pereira, escravo, que, em 1761, curava seus animais com orações. As benzeduras de quebranto e fascinação, causas muito comuns de denúncias ao Tribunal da Inquisição, incluíam a recitação do Pai Nosso, da Ave Maria, e do Credo e também os atos de contrição. Quem delas se utilizava, por exemplo, era Lourença Sousa Campos, preta, viúva, moradora na freguesia de São Pedro, denunciada ao Tribunal da Inquisição de Lisboa, em $1761^{7}$. Nos casos aqui citados, todos recorriam aos elementos mágicos que acreditavam estar presentes em tais orações. A biografia de Madre Victória foi escrita por D. Sebastião Monteiro da Vide, cujo exercício do pastorado na Bahia consistiu numa intensa divulgação das determinações de Trento (JABOATÃO, 1859). Embora condenasse o uso de objetos e palavras sagradas em rituais mágicos o arcebispo dá na biografia, especial destaque às experiências vivenciadas pela freira que apresentam elementos comuns a estes rituais, na medida em que remetem a uma manipulação mágica da realidade. A mesma madre que "quando Madre das Confissões ${ }^{8}$ persuadia [...] a muitas servas, e escravas do Convento para que, precedendo perfeita confissão, dispozessem suas almas, e chegassem dignamente à mesa da Sagrada Comunhão" (JABOATÃO, 1859, p.707), além de curá- 
las de bexiga somente com o auxílio de orações, frequentemente as ajudava a localizar objetos perdidos utilizando como recurso as suas visões. Assim, doutrinadores e doutrinados estabeleceram preferências e destacaram temas e aspectos da crença, de modo a comprometer o conjunto e a ortodoxia da fé. Tanto o clero como o povo incidiram em manipulações mágicas (SILVA, 1982).

Outro aspecto importante da visão cósmica de mundo diz respeito ao papel ativo dos mortos entre os vivos. Esse elemento esteve muito presente no catolicismo e pode ser considerado um importante elemento de convergência com as tradições religiosas africanas. Segundo Schmitt, os mortos assumiram um papel tão especial entre os vivos na cultura cristã medieval que, em 1030, foi instituída a Comemoração dos Mortos, fixada em 2 de novembro. Foi a Ordem de Cluny, de São Bernardo, a responsável pela divulgação desse culto. A liturgia da comemoração dos defuntos tinha como objetivo a ênfase nos esforços para tirar as almas penadas de seus tormentos no além, reafirmando a relação entre vivos e mortos (SCHMITT, 1999, p.93). Mas não foi sempre assim. Na Antiguidade cristã, o clero procurava negar qualquer possibilidade de comunicação entre vivos e mortos. Em seus escritos, S. Agostinho negava que "os próprios mortos possam, em espírito, deslocar-se e intervir realmente no espírito dos vivos." Para Agostinho, os

anjos, sujeitos à vontade divina, fazem os homens conhecer o que eles sabem, por meio de imagens espirituais. [...] essa aparição não tem relação com o corpo real do morto, cujo lugar de sepultura não tem nenhuma importância, nem com a alma do morto, que tampouco tem a preocupação de aparecer (SCHMITT, 1999, p.43).

Entre as concepções de S. Agostinho e a instituição da liturgia dos mortos no século XI, profundas mudanças operaram-se no pensamento cristão sobre os mortos, indicando uma forte influência das culturas ditas pagãs sobre ele. Na Idade Média as imagens dos mortos, não apenas ganharam corporeidade, como moviam-se por si próprias, dispensando a mediação dos anjos e intervindo no cotidiano dos vivos. Em 1137, irmãos da abadia beneditina de Marmoutier, perto de Tours - na França - foram alertados "contra qualquer negligência nos serviços espirituais que devem a seus irmãos defuntos, sob pena de expor-se à vingança destes últimos” (SCHMITT, 1999, p.8687).

João Reis destaca as convergências entre as tradições religiosas africanas e a portuguesa na questão da preparação para a morte. Segundo ele "em ambos os lugares encontramos a ideia de que o indivíduo devia preparar-se para a morte, arrumando bem sua vida, cuidando de seus santos de devoção ou fazendo sacrifícios a seus deuses e ancestrais." Em ambas as concepções de mundo vivos e mortos poderiam interagir, e os primeiros muito poderiam fazer para que os seus mortos tivessem uma segura passagem para o além, "defendendo-se de serem atormentados por suas almas penadas" (REIS, 1991, p.90). Segundo Robert Slenes nas sociedades centro-africanas, "era importante que qualquer morto se sentisse bem despachado para o além”. Essas sociedades: 
"Solidarizavam-se com aquele que ia embora, desejando-lhe uma boa travessia. Mais do que isso, no entanto, procuravam garantir a sorte da própria comunidade. Pois para o sossego dos vivos, o bom fim daquela viagem havia de ser assegurado" (SLENES, 1999, p.251). Na Bahia, Sebastião Barreto, um lavrador de cana português, denuncia ao Santo Ofício, em 1618, que "os negros que vêm da Guiné fazem ao tempo que tiram o doo [luto] por alguma morte uma superstição matando alguns animais e untando-se com o sangue deles e dizendo que então sobe a alma ao céu [...]"9. Os povos yorubás acreditam que "na morte, os componentes do ser humano retornam para os orixás que as redistribuem através dos recém-nascidos." Os componentes imortais, porém, o espírito, podem voltar para a terra, são os Eguns (ELIADE; CLOULIANO, 1999, p.30).

Entre os negros cristianizados a preocupação com os mortos pode ser observada em várias de suas atitudes. Constantemente os libertos solicitavam missas, em seus testamentos, por cônjuges, pais, ex-senhores e escravos falecidos. Alguns solicitavam missas pelas almas do purgatório (OLIVEIRA, 1988). Em 1779, os irmãos da Irmandade de N. Sra. do Rosário dos Pretos da Rua João Pereira obtiveram um breve apostólico, do Papa Pio VI, que tornava o altar da Virgem do Rosário perpetuamente privilegiado ${ }^{10}$. Segundo a doutrina católica, as missas celebradas em altares privilegiados poderiam abreviar o tempo da purgação das almas dos irmãos defuntos, pois através destes altares alcançava-se indulgências, que reduziam os seus dias no purgatório. No ritual católico, os vivos convocam os santos a intercederem pelos mortos. O altar dedicado a Maria transmitia grande eficácia na medida em que a Virgem Mãe ocupava lugar privilegiado como intercessora junto ao Cristo, assumindo, mais que qualquer outro santo, o papel de "advogada dos mortos".

O contato com o "outro mundo" aqui é intermediado por elementos cristãos e ele próprio passa a ser definido por critérios dessa religião. É o chamado "mundo espiritual”, habitado por santos, anjos, mortos e demônios e formado por diferentes espaços - inferno, purgatório, limbo, céu. Seus habitantes se comunicam com os do "mundo natural", mas sob o controle do Deus transcendente. Inspirada numa preocupação com a salvação da alma, estimulando a preparação para o momento da morte, a liturgia dos mortos foi muito mais usada como canal de comunicação com estes. Na tradição popular católica colonial, inclusive, os mortos figuravam "como personagens poderosas, capazes de atormentar ou de ajudar os vivos" (REIS, 1991, p.90). Os sufrágios - missas, preces e esmolas - permitiriam o descanso do morto, e quando não eram cumpridos, este retornava para reclamá-los. No Convento do Desterro, a Madre Victória foi visitada por inúmeras almas que lhes solicitavam missas. Até mesmo uma ex-escrava sua, Luzia da Luz, lhe teria aparecido reclamando missas, que a freira imediatamente mandou celebrar (JABOATÃO, 1859, p.711-712).

Em seu testamento, Marcelina da Silva, segundo a tradição oral, sacerdotiza Ketu-Nagô, solicitou que no dia da sua morte - que ocorreu em 1885 - fosse celebrada uma missa, dedicada à 
pureza de Nossa Senhora, e mais sete missas durante os sete primeiros dias, dedicadas à Paixão de Nosso Senhor Jesus Cristo. Segundo Inês Oliveira, o ritual do axexê perdurava pelos setes primeiros dias a contar do sepultamento. Assim no caso de Marcelina, o ritual cristão e o africano ocorreriam no mesmo período, ambos remetendo a uma preocupação com o destino do morto. Na concepção nagô o rito do axexê é o meio através do qual o morto se liberta, sendo cortados todos os vínculos que o prendem, como existência individualizada, entre os vivos, podendo ingressar completamente no òrun (ELBEN, 1986, p.182).

$\mathrm{Na}$ tradição católica, os mortos para os quais se pediam os sufrágios eram próximos, geralmente familiares, ou irmãos de uma irmandade, pois “a morte de um personagem não põe um termo às relações de parentesco carnal ou espiritual que os vivos mantêm, mas, ao contrário, reativa-as, na lembrança" (SCHMITT, 1999, p.93). Assim, a morte, tanto na tradição católica quanto na africana, tornava-se um forte meio de aproximação entre os membros de uma família, quer fosse ela espiritual ou carnal, na medida em que os vivos mais próximos eram os encarregados de preparar a passagem do morto para o além, assim a "presença" do morto era periodicamente sentida pelos que ficavam.

Retornando a Marcelina, esta recorre à Maria Santíssima, mediadora por excelência dos mortos no além, a ela encomendando a sua alma, missa que deve ser celebrada pela intervenção da sua família cristã - a irmandade. Deixa para sua filha carnal e primeira testamenteira, Maria Magdalena da Silva, a responsabilidade da manutenção dos rituais africanos para a sua morte. Ambos os rituais convergem para uma compreensão da realidade que põe em destaque a relação permanente entre o mundo dos vivos e o dos mortos. Utilizamos o seu exemplo, pois embora fora do período estudado, as referências são seguras quanto a sua vivência de ambas as religiões, e principalmente pela sua posição dentro da hierarquia do candomblé (VERGER, 1992, p.86-94) ${ }^{11}$. Além disso ela remete a uma permanência da observância de rituais católicos entre africanos libertos, num momento em que as irmandades católicas encontravam-se em declínio. Em seu testamento, redigido em 1881, refere-se à prática dos sacramentos, tendo, por exemplo, casado-se conforme o ritual cristão, além de possuir afilhados, revelando a observância do batismo. Em seu testamento lega missas para seu ex-senhor, a esposa e o filho destes, que provavelmente teriam sido os responsáveis pela sua introdução na vivência católica (VERGER, 1992, p.138).

Ao fazer coincidir os rituais funerários do catolicismo e da sua religião ancestral, Marcelina parece estar sendo movida por elementos que vão além de uma tentativa de mascarar a prática da religião africana, com uma "fachada católica". Cumprindo obrigações, Marcelina prepara-se da melhor forma possível para o momento da morte. Deixa à sua filha a função de organizar o seu axexê, para que possa exercer a sua função de ancestral, zelando pela comunidade negra que fica, e à Virgem a de impedir que sua alma permaneça sem descanso, obrigando-a a retornar ao mundo que 
conheceu do lado americano do Atlântico, mundo branco, mas nem por isso menos seu, para solicitar os sufrágios necessários. Sem romper com as raízes ancestrais, Marcelina também partilha os novos valores e crenças, representantes de uma genuína tradição católica.

\title{
O Culto dos Santos Taumaturgos
}

O cristianismo propõe ao pagão convertido uma relação com a natureza intermediada por elementos da fé cristã. A narrativa do padre capuchinho italiano Giovani Antonio Cavazzi de Montecúccolo, que atuou como missionário em Angola no século XVII, revela como isso ocorria em diferentes situações, envolvendo negros batizados. Na aldeia de Sansale, da região de Nsanga, em Angola:

\begin{abstract}
Aconteceu por vezes encontrar as populações a pedirem chuva por meio das costumadas superstições, e [o Padre Jerônimo] procurava então desenganá-las. Mas, às vezes, como os pérfidos feiticeiros fugiam ao seu aparecimento, o povo indignado, ameaçava o padre de morte, queixando-se de que, por aquele ano, as colheitas se perderiam por falta de chuva. Então prometia ele uma boa colheita por virtude do poderosíssimo nome de Jesus. Depois, calcando os objetos supersticiosos do feiticeiro, levantava para o Céu a sua voz, suplicando ao Criador do universo que concedesse aquela graça. Pouco tempo depois, com maravilha universal, caía abundantíssima chuva sobre os campos (MONTECÚCCOLO, 1965, p.414-415).
\end{abstract}

O mesmo padre Jerônimo propôs a substituição das práticas do feiticeiro pelo uso do crucifixo na cura de um doente, sendo bem sucedido.

O culto aos santos católicos foi um importante elemento nesse processo. Não mais podendo estabelecer uma relação direta com a força cósmica, e consciente da inexistência de um caráter divino nesta, o fiel passaria a recorrer ao santo, que teria recebido de Deus o poder de interferir no cosmos. Os santos poderiam intermediar a relação com os seus mortos servindo de mediadores nesse contato; poderiam proteger contra a ação das forças da natureza como o trovão, a chuva, o tempo, o clima, pois possuíam o controle sobre elas; poderiam produzir a cura e a solução de outros problemas cotidianos pois tinham poderes para reverter o mal que as havia produzido.

O poder sobre determinada força cósmica estaria ligado a um momento específico da trajetória cristã do santo. Do mesmo modo como cada força cósmica somente libera uma ação ou energia específica - como o axé específico liberado por cada orixá yorubá -, o santo somente controla ou libera uma força ou poder específico. Enquanto os mitos revelam qual o poder ou energia que cada deus cósmico concentra, as legendas dos santos identificam os seus atributos. Os santos mártires, por exemplo, teriam recebido tal poder através do seu martírio, entendido como ato de confirmação da fé com a própria vida. O seu poder poderia ser sobre uma doença que possuiu, partes do corpo 
mutiladas ou destruídas durante o martírio, ou uma força cósmica que teria manifestado-se por ocasião do seu sacrifício. Assim, Sta. Luzia tornou-se eficiente contra doenças dos olhos - órgão que lhe foi retirado durante o martírio; Sta. Bárbara contra os trovões - que manifestaram-se após sua morte, fulminando o seu pai que teria autorizado o martírio (LA VORÁGINE, 1987, p.896907); S. Lázaro contra chagas - pois conviveu com a doença ao longo de sua vida. No cristianismo, a relação com as forças cósmicas torna-se facilitada pela ação do santo, e neste sentido ocorre uma humanização da natureza. A fé do fiel na eficiência do santo era o caminho, para receber o milagre que "convida a confiar-se à fé, a admitir a onipotência de Deus que transtorna a ordem que ele próprio estabeleceu" (SCHMITT, 1999, p.98).

O culto aos santos, difundido na religiosidade popular, reintegra o cosmos como elemento de comunicação e revelação do sagrado, que habita o mundo invisível. Aos santos se transfere todos os mecanismos usados para estabelecer relação direta com as forças cósmicas divinizadas: sacrifício, oferendas, peregrinações aos seus túmulos, culto a suas relíquias. Os locais onde viveram tornam-se hierofanias do sagrado, assim como os objetos ligados aos seus atributos, partes de suas roupas e do seu corpo, transformam-se em manifestação de sua presença (DUBY; LACLOTTE, 1998, p.31432). Numa tentativa de cristianizar as crenças cósmicas existentes nas diferentes tradições religiosas com as quais manteve contato o cristianismo conseguiu, de certa forma, "desencantar o mundo", mas não sobrepor o Deus criador à sua criação. Mesmo através de uma relação humanizada - santos intermediários - o cosmos receberá sempre o temor reverencial.

Na Bahia do século XVIII, a consciência da humanização da relação com a natureza é algo já perfeitamente assimilado pelo colono, cujo conceito de Deus pressupõe a sua transcendência, cabendo ao santo o simples papel de intermediário. O problema identificado pelo clero, nesse catolicismo popular, era a ênfase no culto ao santo, despertando cada vez mais um interesse no acesso ao seu poder e controle sobre o cosmos, revelando a sobrevivência de crenças pré-cristãs que a Igreja queria extinguir.

As religiões dos africanos trazidos para o Brasil consistiam numa relação direta com as forças cósmicas. Assim, o cosmos era habitado por entidades divinas com as quais o homem mantinha contato direto e permanente. Através da manipulação de elementos específicos era possível estabelecer tal comunicação, necessária para apaziguar e controlar essas forças. Como lembra Juana Elben os orixás, deuses dos povos yorubás, por exemplo, "estão especialmente associados à estrutura da natureza, do cosmos", que interiorizam no ser humano "elementos da natureza e a sua pertença a uma ordem cósmica” (ELBEN, 1986, p.102-3). Neste sentido a humanização da relação com a natureza, através do uso dos santos como intermediários, opõe-se à concepção religiosa africana. Mas a sobrevivência no catolicismo de uma ênfase na necessidade de controle do universo cósmico e de suas ações - razão principal da popularização do culto aos santos, únicos seres 
humanos a deterem esse poder -, abre uma porta para o africano continuar a manter com o cosmos uma relação que para ele é fundamental para a manutenção de sua sobrevivência e a de sua comunidade. Assim seria no culto aos santos taumaturgos, e não no dedicado aos santos negros, que a convergência com o catolicismo tornava-se mais forte, vislumbrando-se nele uma possibilidade de vivência de sua crença ancestral. O caráter salvífico da religião cristã, ao qual estava ligado o culto aos santos negros, não encontrava nenhum sentido quando relacionado aos valores e crenças trazidos para o Novo Mundo.

Vários santos foram cultuados entre a população leiga de Salvador, devido à popularidade do seu poder. Santa Bárbara possuía uma capela na cidade baixa, desde o século XVII. Uma capela foi construída para São Lázaro na segunda metade do século XVIII, sendo ele objeto de grande devoção entre os atingidos por doenças como a varíola. Santos ligados à fecundidade agrícola, como S. João Batista, foram intensamente cultuados em Salvador. Segundo Luís Maldonado o culto a S. João era um dos mais intensos nos países europeus. A associação do santo com o sol - pela coincidência da festa com o solstício de verão - e com a água - através dos sucessivos batismos que teria realizado -, liga o seu culto à fecundidade da terra (MALDONADO, 1975, p.38-39). A tradição popular o associou também à fecundidade feminina. Na Bahia colonial sua festa era uma das mais populares, sendo realizada em 24 de junho.

Pudemos atestar o culto a alguns santos taumaturgos, entre os negros, no século XVIII, indicados a partir de fontes de irmandades e inventários e testamentos de libertos. O século XVIII não traz muitas fontes sobre o culto a santos taumaturgos entre os negros na Bahia, ao contrário do XIX, o que não implica em dizer que ele restringiu-se aos santos aqui destacados. Procissões, novenas, promessas, rezas, relatos de milagres eram formas de divulgar o poder de tais santos, e o negro, por certo, não estava imune a essa circulação do poder sagrado que verificava-se na cidade. A partir da segunda metade do século XIX vemos crescer estudos que registram o cotidiano do negro, daí vêm as fontes que remetem a tais cultos, muitos deles prováveis sobrevivências do século anterior. Autores como Nina Rodrigues, Manuel Querino, Silvio Romero escreveram estudos sobre a influência do negro na formação da sociedade brasileira, iniciando seus estudos na segunda metade do século XIX. Esses autores remetem à questão do "sincretismo" entre deuses africanos e santos católicos, o que indica que o culto aos últimos era comum entre os negros. Relação essa que pode ser inclusive explicada a partir da convergência entre as religiões africanas e a visão cósmica presente no culto cristão que aqui estamos abordando. Autores como Roger Bastide, René Ribeiro, em estudos sobre religiões afro-brasileiras no século XX, chamaram a atenção para a convergência entre as funções dos santos e orixás sincretizados nessas diferentes tradições religiosas, como o tambor em São Luiz do Maranhão, o xangô no Recife e o candomblé na Bahia. Em obra da década de noventa do século XX, Sérgio Ferreti aborda essa mesma questão ${ }^{12}$. As fontes do século XVIII 
são em sua maioria registros de atividades das irmandades de negros, os poucos ainda preservados, e eles somente remetem aos santos cultuados nessas instituições, de certo modo controladas pelo clero. Assim, é sobre esses santos que nos deteremos.

Segundo Renato da Silveira, o culto a São Jorge foi organizado por ferreiros e serralheiros nagôs que estavam filiados à irmandade do Senhor Bom Jesus dos Martírios, tendo possivelmente entrado na irmandade como patrono intercessor acompanhando o Senhor dos Martírios no altar de N. Sra. da Piedade, na Igreja da Barroquinha. No início do século XIX, esses irmãos participavam da procissão de Corpus Chisti, levando a bandeira do santo (SILVEIRA, 2006). Cavaleiro cristão, S. Jorge teria sido um mártir que morreu na Palestina, provavelmente numa época anterior a Constantino. Segundo sua legenda ele teria vencido um dragão que estaria prestes a devorar a filha do rei de uma cidade chamada Silene. Com tal milagre o povo da cidade havia convertido-se ao cristianismo, sendo morto, tempos depois, devido a uma perseguição aos cristãos. A punição ao Governador Daciano, em tempos dos Imperadores de Roma Dioclesiano e Maximiano, que autorizou o seu martírio e morte, foi ser devorado por fogo descido do céu. As lendas que circulavam durante a Idade Média, em especial na Inglaterra, remetiam a diferentes aparições do santo em batalhas, auxiliando os exércitos dos cruzados ${ }^{13}$.

Consta na obra História Artística do Ocidente que S. Jorge penetrou com força no Ocidente exatamente por ocasião das cruzadas, desembarcando primeiro na Itália, onde ocupou o seu lugar em Gênova e Veneza. Depois, Barcelona, a Ordem Teutônica e o reino da Inglaterra fizeram dele o seu santo tutelar (DUBY; LACLOTTE, 1998, p. 311). Em Portugal seu culto foi organizado a partir de 1385, ganhando maior destaque ao substituir S. Tiago como patrono do reino. S. Jorge era especificamente o patrono dos cavaleiros, dos guerreiros e de todos os profissionais a seu serviço como ferreiros, armeiros, serralheiros e os demais oficiais mecânicos que militavam em ferro e fogo. Quem controla o fogo, tem o poder também sobre o ferro. Como S. Bárbara, cujo trovão marcou um momento do seu martírio fulminando seu pai, no martírio de S. Jorge o fogo descido do céu matou o imperador que ordenara sua morte. Sobre o fogo o santo mantinha controle, tornandose o protetor de todos os que com ele trabalhavam.

Um importante culto foi o dedicado a Sant'Ana, mãe de Maria, que devido a ênfase institucional no culto da sagrada família foi presença constante dos oratórios particulares e alfaias de diferentes irmandades em Salvador, juntamente com S. José e S. Joaquim. Celebrada no Ocidente em 26 de julho, sua festa foi instituída em 1584, mas o seu culto data do século VI, quando o Imperador Justiniano I dedicou-lhe um templo. Ela não é citada na Bíblia e as referências à sua existência são do texto apócrifo Protoevangelho de Tiago. A intensa devoção à Sant'Ana a partir da metade do século XIV, tornou-a alvo de severas críticas de Lutero, durante o movimento de reforma protestante ${ }^{14}$. Em Salvador, o calendário eclesiástico de 1784 revela que novenas em 
homenagem a Sant'ana ocorriam em várias igrejas da cidade, sendo iniciadas em 18 de julho. A festa era celebrada na matriz de Sant'Ana, na Sé, na Conceição da Praia, em S. Francisco, dentre outras. As irmandades de N. Sra. do Rosário dos Pretos: da Rua João Pereira, dos Quinze Mistérios e do Carmo, possuíam imagens da santa em suas alfaias ${ }^{15}$. Ela aparece também nos oratórios particulares de alguns dos negros libertos que pesquisamos.

Hildegardes Viana lembra a relação cósmica presente no culto à mãe de Maria, na Bahia. Na memória popular recuperada pela autora, Sant'Ana, cuja festa ocorre num mês de intenso frio e de chuvas na região, era lembrada como uma:

velha decrépita, tão decrépita que molhava os lençóis com qualquer neném. A santa ficava enregelada, sem poder se levantar, tilitante, tentando se embiocar nas roupas úmidas. Ficava a pobrezinha mortinha de frio, esperando que Santa Clara chegasse em agosto e o tempo melhorasse. Quando a santa chegava lhe dava um caldinho quente, Santana ganhava forças nas pernas e dependurava os lençóis ao vento. Então havia mais quentura. E quando friorentos sofressem de decrepitude ou reumatismo rezavam para maior glória da caluniada mãe de Maria, para que tivesse força de se levantar e enxugar as panaradas molhadas, para que pondo a roupa a secar acabasse com aquele tormento. Enfim, todos aguardavam que Santana desse ou mandasse bom tempo, com menos umidade e mais calor (VIANA, 1960, p.9-10).

Na tradição popular o frio de julho era justificado por ser o mês de Sant'ana. Como anciã Sant'ana mais do que qualquer outro santo era capaz de sentir os estragos do tempo e do frio sobre o corpo humano. Como detentora de um poder divino poderia controlar essa força cósmica, a do clima, de modo que não interferisse na saúde de seus devotos. Esses rezavam para serem beneficiados com o seu poder sobre o frio, em especial os que sofriam de reumatismo, daí o seu culto, esperando da santa que ela "desse bom tempo, com menos umidade e mais calor". Manipulando forças cósmicas idênticas às representadas pelos deuses africanos, estes santos abrem o caminho para uma introdução da vivência do cristianismo pelos africanos. Apresentam uma possibilidade de assimilação da liturgia católica e de manutenção de suas crenças e valores ancestrais.

Aqui a ação de Sant'Ana lembra a atribuída aos orixás na definição deles feita por Pierre Verger. Segundo ele, os orixás podem ser definidos a partir de dois elos que se juntam: primeiro, como uma parte da natureza "sensata, disciplinada, fixa, controlável, que forma uma cadeia nas relações dos homens com o desconhecido" ou como um ancestral divinizado "que viveu outrora na Terra e que soube estabelecer esse controle, essa ligação com a força, assentá-la, domesticá-la, criar entre ela e ele um laço de interdependência, através do qual atraía sobre ele e os seus a ação benéfica e protetora dessa força e direcionava seu poder destruidor para seus inimigos; em contrapartida, esse ser humano fazia a essa parte da força fixada, sedentarizada, as oferendas e os 
sacrifícios necessários para manter seu poder, seu potencial, sua força sagrada, denominado ase" (VERGER, 1999, p.37-38). Destacamos nesta definição a relação estabelecida com as forças da natureza, que também aplica-se aos voduns, deuses originários da região do Daomé. Assim, temos entre os orixás yorubás Yemanjá divindade das águas salgadas; Xangô, divindade do trovão; Yansã, divindade do vento e tempestade, e única que mantinha o domínio sobre as almas dos mortos (eguns); Oxum, divindade das águas doces (VERGER, 1999, p.32-33.). O culto a esses deuses destina-se à manutenção da aliança celebrada com a força da natureza, de modo a mantê-la sobre o controle do grupo humano.

Lembrada pela sua velhice, Sant'Ana remete a importância da ancestralidade no contexto da sua devoção, dela advindo o seu poder. A força de S. Jorge, como santo guerreiro e como protetor dos que trabalham com o ferro, lembra a de orixás que têm o poder de assegurar a "possibilidade de exercer certas atividades como a caça, o trabalho com metais ou, ainda, adquirindo o conhecimento das propriedades das plantas e de sua utilização" (VERGER, 1981, p.18). Temos, por exemplo, Ogum, um dos orixás dos povos yorubás, que é a "divindade dos ferreiros, das guerras, dos agricultores e de todos aqueles que trabalham com o ferro e o utilizam" e Oxossi, divindade dos caçadores (VERGER, 1999, p.32). Os povos da África Central também possuíam diferentes deuses que exerciam poderes específicos sobre as forças cósmicas. As relações com esses deuses eram estabelecidas a partir dos "feiticeiros" e dos sacrifícios a eles oferecidos, conforme orientação do "feiticeiro". Em sua narrativa, o padre Cavazzi descreve muitos desses cultos nos reinos do Congo, Matamba e Angola. Entre as divindades cultuadas por esses povos temos as ligadas às águas. Segundo o Padre Cavazzi, os negros ao atravessarem rios ou lagos:

Julgando que o movimento é indício de vida também as águas ou acreditando que é uma divindade qualquer que as perturba, ou as acalma, os idólatras param na margem e cumprimentam as águas. Depois suplicam que lhes concedam benignamente a passagem, sem incômodo e sem perigo. Bebem um bocado e amassam um pouco de barro, com que traçam no peito alguns sinais misteriosos. Por fim, com maravilhosa segurança, lançam-se ao rio para o atravessar (MONTECÚCCOLO, 1965, p.118).

O padre relata que nas margens dos rios e lagos "há sempre altares, casas e abrigos para os ídolos que presidem as águas". Havia feiticeiros ligados ao culto dos fenômenos atmosféricos - os Mpindi -, possuindo domínio sobre todos eles, especialmente os trovões e a chuva. O padre referese também aos Amobundu, feiticeiros responsáveis pela guarda das sementeiras, associado por certo a um importante culto de divindades ligadas à fecundidade da terra.

Na América Colonial nenhuma devoção cristã mereceu maior estímulo entre os negros do que o culto à Virgem Maria. N. Sra. do Rosário foi a invocação mais popularizada. No início do século XVIII, a maior parte das paróquias de Salvador e recôncavo possuíam devoções negras dedicadas 
ao rosário, criadas pela iniciativa tanto dos párocos quanto dos padres jesuítas ${ }^{16}$. Outras invocações também são objeto deste culto como N. Sra. da Boa Morte, N. Sra. da Conceição, N. Sra. do Parto (CAMPOS, 1941, p.491-493). Os atributos destacados nestas devoções - relação com a morte, o nascimento - reafirmam o seu status de divindade e a ligação do culto mariano com as forças cósmicas, que parecem justificar sua popularização. N. Sra. da Boa Morte celebrada em 15 de agosto, era invocação muito festejada em Salvador. A procissão ocorria em tempos coloniais na Saúde, em S. Domingos, em S. Francisco, em Sant'Ana, na Palma, no Carmo, nos Perdões, na Santíssima Trindade e em inúmeras outras igrejas. Uma devoção a N. Sra. da Boa Morte existiu entre os irmãos da Irmandade do Senhor do Martírio, composta de negros de origem yorubá, na Igreja da Barroquinha, que adquiriu grande prestígio, revelando a importância dada por esses negros ao rituais ligados à passagem para o além, aos quais essa invocação à Virgem também remetia, por estar associada ao episódio da morte e ascensão de Maria aos céus.

\section{Considerações Finais}

A relação de diferentes santos católicos com o cosmos - e o número destes vai além dos aqui citados - foi um elemento fundamental para a expansão do cristianismo entre os negros, pois permitiu-lhes uma prática mais constante desta religião. Embora essa prática não tenha ocorrido segundo os critérios da catequese formal - cuja ênfase era a prática sacramental, onde residia o núcleo básico da fé cristã -, ela foi fonte de genuínas experiências cristãs católicas.

\section{Referências Bibliográficas}

AGOSTINHO, Bispo de Hipona. Sermões de Natal e Epifania. São Paulo: Paulinas, 1959.

BUTLER. Vida dos Santos. Abril (IV). Edição completa organizada, revisada e ampliada por Herbert Thurston, S.J. e Donald Attwater. Petrópolis: Vozes, 1984.

BUTLER. Vida dos Santos. Julho (VII). Edição completa organizada, revisada e ampliada por Herbert Thurston, S.J. e Donald Attwater. Petrópolis: Vozes, 1989.

CAMPOS, João da Silva. Procissões Tradicionais da Bahia, publicação do Museu da Bahia, número $01,1941$.

DELUMEAU, Jean. Religião Oficial e Religião Popular na França durante a Reforma e a ContraReforma, Concilium, Revista Internacional de Teologia, Lisboa, v. 4, 1986.

DENZINGER, Enrique. El Magistério de la Iglesia: manual de los símbolos, definiciones y declaraciones de la Iglesia en materia de fe y costumbres, Barcelona: Editorial Herder, 1955. 
DUBY, Georges; LACLOTTE, Michel. História Artística da Europa. Tomo II. Rio de Janeiro: Paz e Terra, 1998, p. 314-327.

ELBEN, Juana. Os Nagôs e a Morte: Pàdê, Àsèsè e o culto Égun na Bahia. Petrópolis: Vozes, 1986.

ELIADE, Micea. Tratado de História das Religiões. São Paulo: Martins Fontes, 1998.

; COULIANO, Ioan P. Dicionário das Religiões, São Paulo: Martins Fontes, 1999.

JABOATÃO, Antônio de Santa Maria (frei). Novo Orbe Seráfico Brasilico ou Chronica dos Frades Menores da Província do Brasil [1761]. V. I. Rio de Janeiro: Typografia Brasiliense de Maximiano Gomes Ribeiro, 1859.

KARASCH, Mary. Slave Life in Rio de Janeiro (1808-1850). New Jersey: Princeton University Press, 1987.

LA VORÁGINE, Santiago de. La Leyenda dorada [1260], vol. II. Traducción del Latín: Frey José Manuel Macías. Madrid: Alianza Editorial, 1987.

MALDONADO, Luis. Religiosidad Popular: nostalgia de lo magico. Madrid: Ediciones Cristiandad, 1975.

MATTOSO, Kátia M. de Queirós. Ser Escravo no Brasil. $3^{\circ}$ ed. São Paulo: Brasiliense, 1990.

MINTZ, Sidney W.; PRICE Richard, The Birth of African-American culture na anthropological perspective. Boston: Beacon Press, s/d.

MONTECÚCCOLO, João Antônio Cavazzi de (padre). Descrição Histórica dos Três Reinos: Congo, Matamba e Angola [1 $1^{\text {a }}$ edição na Bolonha em 1687], vol. I, Lisboa: Junta de Investigação do Ultramar, 1965.

MOTT, Luiz. Cotidiano e vivência religiosa: entre a capela e o calundu. In: SOUSA, Laura de Mello e (org.). História da Vida Privada na América Portuguesa. V. I. São Paulo: Companhia das Letras, 1997.

. O Liberto: seu mundo e os outros. Salvador, 1790/1890. São Paulo: Corrupio, 1988.

OLIVEIRA, Maria Inês Côrtes. Quem eram os 'Negros da Guiné'? A origem dos africanos na Bahia. Afro-Ásia, v.19-20, 1997.

OLIVEIRA MARQUES, A. H. A Sociedade Medieval Portuguesa: aspectos da vida cotidiana. Lisboa: Livraria Sá da Costa, 1974.

REIS, João José. A Morte é uma Festa: ritos fúnebres e revolta popular no Brasil do século XIX. São Paulo: Companhia das Letras, 1991.

SCHMITT, Jean-Claude. Os Vivos e os mortos na sociedade medieval. São Paulo: Companhia das Letras, 1999.

SILVA, Cândido da Costa e. Roteiro da vida e da morte: um estudo do catolicismo no sertão da Bahia. São Paulo: Ática, 1982. 
SILVEIRA, Renato. O candomblé da Barroquinha: processo de constituição do primeiro terreiro baiano de Keto. Salvador: Ed. Maianga, 2006.

SLENES, Robert. Na Senzala uma Flor: esperanças e recordações na formação da família escrava - Brasil sudeste, século XIX. Rio de Janeiro: Nova Fronteira, 1999.

THOURTON, John. Africa and Africans in the making of the Atlantic world, 1400-1680.

Cambridge University Press, 1992.

VAUCHEZ, André. A Espiritualidade na Idade Média Ocidental séculos VIII a XIII. Rio de Janeiro: Jorge Zahar ed., 1995.

VERGER, Pierre. Orixás Deuses Iorubás na África e no Novo Mundo. Salvador: Corrupio, 1981. . Fluxo e Refluxo do tráfico de escravos entre o Golfo do Benim e a Bahia de Todos os Santos dos séculos XVII a XIX. Salvador: Corrupio/ Brasília: Ministério da Cultura, 1987.

. Os Libertos sete caminhos na liberdade de escravos da Bahia no século XIX. São Paulo: Corrupio, 1992.

- Notas sobre o culto aos orixás e voduns na Bahia de Todos os Santos, no Brasil, e na Antiga Costa dos Escravos, na África. São Paulo: Edusp, 1999.

VIANA FILHO, Luiz. O negro na Bahia. Rio de Janeiro: José Olympio, 1946.

VIANA, Hildegardes. Festa de Santos e Santos Festejados. Salvador: Livraria Progresso Editora, 1960.

\section{NOTAS}

${ }^{1}$ ANTT, Caderno do Promotor, 121, folha 72. Documento gentilmente cedido pelo Professor Doutor Luiz Mott.

${ }^{2} \mathrm{O}$ caso de Jacobina encontra-se descrito em: MOTT, Luiz. Quatro Mandigueiros de Jacobina na Inquisição de Lisboa. Afro-Ásia, v.16, pp. 148-160, 1995.

${ }^{3}$ D. Sebastião Monteiro da Vide, Notícias ao Arcebispado da Bahia para suplicar a Sua Majestade em favor do culto divino e salvação das almas In: RIHGB. Tomo LIV, Parte I.

${ }^{4}$ Pierre Verger divide o tráfico para a Bahia em quatro fases: o ciclo da Guiné (segunda metade do século XVI), o ciclo de Angola (século XVII), o ciclo da Costa da Mina (nos três primeiros quartos do século XVIII) e o da baía do Benin (entre 1770 e 1850) (VERGER, 1987, p.7). Lembramos aqui Inês Oliveira, que informa serem os negros embarcados na terceira e quarta fase acima especialmente jejes (daomeanos) e nagôs (iorubas) e outros de algumas nações cujos cativos eram embarcados na Costa do Leste ou Costa a Sotavento do castelo de são Jorge da Mina (OLIVEIRA, 1997, p.58).

${ }^{5}$ Constituições Primeiras do Arcebispado da Bahia feitas e ordenadas pelo Arcebispo, Propostas e aceitas em Sínodo Diocesano (12 de junho de 1707). Coimbra, Real Colégio das Artes da Companhia de Jesus, 1720, nº $900,901$.

${ }^{6}$ Idem, ${ }^{\circ} 900$.

${ }^{7}$ ANTT, Caderno do Promotor, 125, folha 112. Documento gentilmente cedido pelo Professor Doutor Luiz Mott.

${ }^{8}$ O termo Madre das Confissões aplica-se à religiosa responsável em preparar a comunidade para confessar-se.

${ }^{9}$ Segunda Visitação do Santo Ofício às partes do Brasil - Denunciações da Bahia (1618 - Marcos Teixeira), introd. Rodolfo Garcia. In: Anais da Biblioteca Nacional do Rio de Janeiro, vol. 49, 1927, p. 178.

10 "Breve Apostólico que obtiveram os suplicantes irmãos da Confraria de N. Sra. do Rosário dos Pretos da rua João Pereira para terem um altar privilegiado". Arquivo da Cúria Metropolitana de Salvador, Caixa 161 - Br 7, Doc. 02.

${ }^{11} \mathrm{O}$ testamento de Marcelina está transcrito nesta obra nas páginas 138-141.

12 QUERINO, Manuel. A raça africana e os seus costumes na Bahia. In: Anais do $5^{\circ}$ Congresso Brasileiro de Geografia. Bahia, 1916. QUERINO, Manoel. Costumes africanos no Brasil, Rio de Janeiro: Civilização Brasileira, 1938. RODRIGUES, Nina. O Animismo Feitichista dos negros baianos, Rio de Janeiro: Civilização Brasileira, 1933 (1ª publicação: 1896); ROMERO, Sílvio. História da Literatura Brasileira: Contribuições e estudos gerais para o exato 
conhecimento da literatura brasileira. $4^{\mathrm{a}}$ ed., Rio de Janeiro: Livraria José Olympio Editora, 1949; BASTIDE, Roger. As religiões africanas no Brasil: contribuição a uma sociologia das interpenetrações de civilizações, vol. II, São Paulo: Livraria Pioneira Editora/ Edusp, 1971; RIBEIRO, René. Antropologia da Religião e outros estudos, Recife: Ed. Massangana - Fundação Joaquim Nabuco, 1982; FERRETI, Sérgio. Repensando o Sincretismo, São Paulo: Edusp/ Fapema, 1995.

${ }^{13}$ Vida dos Santos de Butler, Mês Abril, Petrópolis: Vozes, 1984, p. 187-188.

${ }^{14}$ Vida dos Santos de Butler, Julho (VII), edição completa organizada, revisada e ampliada por Herbert Thurston, S.J. e Donald Attwater. Petrópolis: Vozes, 1989, p. 237-238.

15 "Tombo dos Bens da ordens terceiras, confrarias e irmandades da cidade de Salvador instituído em 1853". Publicações do Arquivo Público da Bahia, vol. VI, Bahia, Imprensa Ofícial, 1948. Ver também o “Termo do Inventário a que procedeu a Nova Mesa administrativa da Irmandade de N. Sra. do Rosário das Portas do Carmo dos bens, alfaias, utensílios pertencentes a esta venerável Irmandade como abaixo declara, 07 de fevereiro de 1892”. Arquivo da Ordem Terceira do Rosário das Portas do Carmo, Caixa 02, Documento, 01. Este é o inventário mais completo da irmandade dentre os que ainda existem.

${ }^{16}$ SANTA MARIA, frei Agostinho de. Santuário Mariano e História das Imagens Milagrosas de Nossa Senhora (1722), Instituto Histórico e Geográfico da Bahia, $9^{\circ}$ vol., 1949. A partir dos dados informados nesta obra temos 22 devoções de negros, 06 em Salvador, 13 no recôncavo e 3 no sul da capitania, algumas transformadas em irmandades.

Artigo recebido em 03/2010. Aprovado em 05/2010. 